DOI: $10.37393 / J A S S .2020 .01 .6$

\title{
MODEL FOR CONDITIONAL TRAINING OF ELITE FEMALE VOLLEYBALL PLAYERS
}

\author{
Julian Karabiberov
}

National Sports Academy "Vassil Levski”, Sofia, Bulgaria

ORCID

Julian Karabiberov https://orcid.org/0000-0003-1972-7237

\begin{abstract}
The manuscript presents the model for conditional training implemented in 2018 in the new female volleyball national team. The methods of the Bulgarian training system Fit Motion-Professional were used with a female national team for the first time. The training scheme follows the modular principle and is based on innovative methods and principles, various means and parallel-consecutive planning aimed mostly at the development of the motor qualities in each module. The interrelations between the basic motor qualities have been surveyed as well as the dynamics in their development at the different stages and in the different modules, and their efficiency in the volleyball game. The major aim of this manuscript is to study the efficiency of the model for conditional training of elite female volleyball players.

Some new equipment and facilities have been designed for functional-conditional training in relation to the team's preparation.

In order to prove the higher efficiency of the model compared to the standard conditioning training used in Bulgaria, an experiment was further carried out with the Republican Women's Volleyball Champion, the team of Maritsa Plovdiv.
\end{abstract}

Key words: conditional training, modular planning scheme, female volleyball

\section{INTRODUCTION}

Conditional training is an intrinsic part of the training process of athletes with different qualification, practicing different kinds of sports. In sports theory and practice an athlete's organism is viewed as a dynamic system with information behavior. According to this concept, in the process of self-regulation of an organism, we can observe a choice of different formative training structural-functional systems among the one of relatively highest functional significance. In the "theory of chaos", the attractive system is called an attractor. The attractor bears the major characteristics of a functional ability, but at the same time, the attracted various structural elements, built in the process of training, leave certain traces (Gadev, 2015, 2017). Thus, in the sense of the mechanism "transfer of training" a new "physiologically adapted functional system" is formed with predominant direction of functional behavior.

There is a great number of surveys in the literature. Some methods for development of certain physical qualities have been devised in different kinds of sport (Wilmore, Costill, 1994; Suslov, 1999; Bomba, Carrera, 2005; Panayotov, 2018). Miladinov offered some methods for development of explosive power among football players and gymnasts (Miladinov, 2005, 2008).

Overall concept:

Creation of optimal conditions (through parallel - sequentially applied training exerci- 
ses) for self-organization of the body's functions for the purpose of self-building, based on optimally made managerial decisions by the trainer.

Training exercises are auxiliary because they do not prepare the athletes to participate in weightlifting, bodybuilding, athletics, but to play good volleyball. They have to serve the game of volleyball!

Each of the means, or forms of action in modules, as carriers of accurate encoded signals, is interwoven in the previous ones, leaving traces of specific effects that oblige the body to self-organize and form a new quality state with advanced functions.

Formation of motor skills in playing ball with dynamic use of the already accumulated power-speed potential, along with the development of special tactical and technical habits, is embedded in each of the training modules we offer.

The modules are designed on the basis of three sports and physiological principles:

1. conditioning is essentially related to cerebral cortex regulation of movement, mental activity, individual psycho-analytical abilities and the athletic intelligence of volleyball players;

2. conditioning training allows building models of game reactions to contestants integrating in game-efficient physical and technical tactics complex;

3. conditioning training is the realization of a "masterfully" formed by a sports educator/ coach/training algorithm - the end result of the algorithm is the integration of all / advanced to high level / volleyball-specific motor actions into relevant overall games that serve the game strategy.

The aim of the present study is to survey the efficiency of a model for conditional training of elite female volleyball players (middle aged
23,7 years, height $183 \mathrm{~cm}$ and weight $69,7 \mathrm{~kg}$ ). Tasks of the research:

1. To design a program for conditional training while abiding by the principles of the model which is offered,

2. To investigate changes in the level of motor skills and the extent to which they are used in a gaming environment during the application of the model.

3. To make a comparative analysis of the development of motor skills and the effectiveness of their use in a gaming environment, for both tested groups of athletes.

\section{METHODS}

The introduced model for conditional training consists of 4 modules with different duration and priorities in the training process such as abiding by the "Principle of the dominant". The changes in the character of the training process inside the different training modules are gradual while the changes between the different modules are uneven as regards their direction and intensity. They are aimed at as essential variations as possible in the levels of the basic physical qualities - force, velocity and tenacity, and respectively in the degree of destabilization of the functional systems of the organism of the researched individuals.

\section{Duration of the study}

The duration of the study was 13 weeks and included identical in content and structure modules, both in the methodology used in 2018 with the National Team and in the additional experiment with the team of Maritsa.

\section{Object of the study}

18 contestants from the National Volleyball Team of Bulgaria and 18 contestants from the Maritsa team aged 18-28 were the subject of the study. The Maritza team players were uniformly distributed both in age in playing positions 
into 2 groups of 9 people - one experimental and one control. The control group used a conventional conditioning training methodology, while the experimental team implemented that of the National Volleyball Team.

\section{Planning and execution of the prepara- tion}

The introduced model for conditional training was implemented with the competitors from the female national volleyball team - a total of 18 athletes.

The experiment was held in the period April 2018 - September 2018.

The model of conditional training was split into two stages so that the athletes could get into good sports shape and take part in the two most important yearly tournaments:

Stage 1 - from 23 April to 20 June.

Stage 2 - from 26 June to 28 September.

The module scheme of the Bulgarian training system ,JKFitMotion - Professional” was used.

Module 1 (basic)

In this module we paid particular attention to preventive-stabilizing and balance exercises and the work of professional kinesitherapists (Nikolay Kasabov) was very useful. There were also exercises for mobility and control of movements (Eremiev, 2004) as well as some means which helped the coordination improvement. We developed some abilities for control and coordination of the movements of the different parts of the body by using a great number of various exercises performed on horizontal ladder, with markers, resistance bands, etc. The preventive-stabilizing and balance exercises were gradually made more dynamic and technically complex (Eremiev, 2009, 2010). Gradually some of the preventive exercises in the trainings were excluded from the scheme and the static ones were to- tally abandoned. Their place (until the end of the $6^{\text {th }}$ week) was taken by preventive-dynamic means (Karabiberov, 2016) which were transformed into functional-coordination exercises.

In the strength endurance training the typical methods of bodybuilding workout were used, which is characterized with slow motions executed in a 2-sec concentric phase and a 4-sec eccentric phase. This allowed us (at the end of the $2^{\text {nd }}$ week of the training process) to include the slow-dynamic method with intensity 83 $88 \%$ of the repeated maximum (1RM), with the duration of the single repetition $8 \mathrm{sec}$ and number of repetitions per set - up to 5 . The slow-dynamic method developed for the volleyball players' needs (Wilkie, 1949; Ramey, 1976; Bobbert, 1990; Linthorne. 2007; Miladinov et al., 2009) was used until the end of the $3^{\text {rd }}$ week from the beginning of the team preparation. During the $4^{\text {th }}$ week of the preparation ( $2^{\text {nd }}$ part of the module) we included the method of the maximum efforts which is characterized with the use of maximum and around maximum muscle tension with intensity of over $88 \%$ of the $1 \mathrm{RM}$, number of repetitions - fewer than 5 (most often 3-4) and long breaks between the sets with the aim of maximal recovery. The period of predominance of this method was 2 weeks; after that it was practiced once a week.

The training program aimed at developing speed at the beginning of the preparation consisted only of exercises for maximum frequency of motions and speed of a single movement. At the end of the fifth week we began a priority work for speed of reaction through the use of starts from different initial positions, speed of transition from eccentric into concentric work of the muscle contractions as well as through other training options. We would like to point out that during the first module, we relied more on the circle activities and strength methods in the series of exercises during dense training sessions (Panayotov, et al., 2018). 


\section{Module 2 (speed-strength)}

The main training means were athletics exercises - plyometric jumps and ballistic throws with medicine balls. In this way the speed component was inbuilt in the force one with the aim to form the specific motor quality explosive power.

The work aimed at development of strength continued with two training sessions weekly and the exercises were reduced to the most important regional ones with free weights (dumbbells and barbells).

The work aimed at the development of speed in all its forms and mostly at speed of reaction, speed of a single motion, and speed of transition from eccentric to concentric muscle contraction, was also among our priorities. The athletes playing Libero and Setter used with priority starts from different initial positions and dashes with maximum speed and length of 15-20 meters.

The anaerobic endurance was developed through specific strength-speed dense trainings, and the aerobic tenacity - through recovery cyclic exercises of moderate intensity.

Prior to the main part of the special trainings we mastered the athletes' coordination skills mostly through exercises close to the competitive ones as regards their kinematicdynamic structure.

\section{Module 3 (accumulative stabilizing)}

The most often used training activity was functional-coordination one. It was the continuation of the potentially synergetic highly intense athletics work performed in the previous module. The training means of this system connected the characteristic strength and athletics movements into exhaustive specialized complex actions similar to volleyball game and helped the realization of an effective successful play. The means were characterized with high intensity and coordination complex- ity - the duration of the execution was $20 \mathrm{sec}$ followed by a rest period of $20 \mathrm{sec}$. We used 8 exercises which engaged the whole-body muscles with an emphasis on the muscles of the lower limbs. The shortened rest intervals affected positively the anaerobic speed tenacity and the ability of the organism to perform a stable work in conditions of hypoxia and disturbed alkaline-acid balance.

Besides these types of activities, there were some exercises for development of agility which were characterized with great speed, accuracy and special direction, with increasing coordination complexity. The specialization of the exercises required the more frequent use of group games in teams of three or four.

In this module the training work aimed at development of speed was done just before the main parts of the special training activities as well as prior to the functional-coordination conditional trainings sessions.

There were two strength trainings per week. The first training emphasized on the maximum force, and the second one - on its transformation into velocity impacts. After the main strength movements, the contrasting method with 3-4 speed exercises after a break of $22 \mathrm{sec}$ was used.

\section{Module 4 (realization-competitive)}

During this last module from the scheme we used, the motor activities in the play aimed at victory were mastered. The most important thing was to work for the athletes' special agility and development of abilities to create cognitive-program models of behavior subjected to different play situations with the aim of best realization.

The typical strength training where we used the method of maximum efforts was held once a week as a maintaining training which did not allow the maximum strength to drop with more than $5 \%$. The competitors playing Libero did 
not use this method. It was replaced with the repeated method for strength endurance. The explosive power and velocity in its basic forms maintained the level they had reached at the end of the previous period.

A 5-week basic-preparatory period during which general strength training including TFP, circuit and bodybuilding type workouts are applied. Strength exercises with local and regional impact with free weights and machines were used. Three training sessions per week were performed. During this period, general endurance was also trained, using continuous aerobic cycling exercises on a bicycle, running treadmill and climbing on a climbing machine. After week 4 interval training sessions for developing strength and speed were also included. Different combinations of shortened jumps were used at a distance of $30-50 \mathrm{~m}$ in order to develop the jump resistance.

A 3-week long special preparation period that used typical athletics means for explosive power and speed development was incorporated. The repetitive method was used for running, jumping, and ballistic throwing exercises with weights. It was aimed at developing maximum speed, jumping abilities, and explosive strength. Continuous low-intensity aerobic exercise was used occasionally for recovery purposes only.

A 2-week long pre-competition period that used combinations of typical strength exercises with submaximal and maximum weights, jumping and throwing exercises with thick balls. To transform the acquired motor abilities into effective gaming capabilities, we relied mainly on increasing the volume of modelling and competitive volleyball games.

A 3-week long competition period, using the principle of the specialized diversity as a priority, through gaming training and control and competition games. Power drills took place once a week, as well as athletic training.

\section{RESULTS AND DISCUSSION}

Table 1 presents the results from the conducted tests with the equipment Dynostick (Germany) and the equipment provided by SC Maritsa-mobile accelerometers:

Table 1. Change in the force and explosive power indexes in the course of the implementation of the model for conditional training

\begin{tabular}{cccccccc}
\hline $\begin{array}{c}\text { Index } \\
\text { Module }\end{array}$ & F max & H max & H max1 & Hmax/game & H1/game & HL/game & Ef \\
\hline Beginning & 56 & 49 & 52 & 51 & 35 & 30 & 39 \\
$1-2$ & 92,5 & 68 & 71,8 & 70 & 51 & 41 & 51 \\
$3-4$ & 90 & 78,5 & 84,8 & 84,2 & 63 & 58 & 70 \\
\hline
\end{tabular}

Legend: Fmax-maximum force, front squat with a barbell in $\mathrm{kg}$;

Hmax - maximum height of the jump from place in $\mathrm{cm}$;

Hmax 1-maximum height of the jump with acceleration of 2 steps in $\mathrm{cm}$;

Hmax/game - maximum height of the jump in play;

Hl/game-average height of the jump in play;

HL/game - height of the last jump in play;

Ef-Special Motion Efficiency in Play

Note: The introduced indexes are average for the team. The decrease in the augmentation of play jumping tenacity as regards the maximum height of the jumps compared to their maximum height in play trainings is due to the increased and intense play time and consequently due to a higher degree of fatigue. 
The Ef index is calculated by a coefficient the beginning of the $3^{\text {rd }}$ stage had increased derived from the results obtained in the performance of a specially designed test, which evaluates the time to perform special motion actions - moving, blocking and dunking. The execution time and the accuracy of the play for which a certain number of points are scored are evaluated. The coefficient is equal to the sum of the points obtained divided by the time of execution of the complex. with $60.5 \%$ and showed a slight drop of nearly $3 \%$ at the end of the $4^{\text {th }}$ stage. The height of the jump increases more significantly during the first 2 stages of the preparation because of the increase of the strength component which depends on the maximum force. Information on this is also provided by the increase of the benchmarks: an average in-game jump height of $80 \%$, a last jump height indicator of over

Tables 2 and 3 show within-group differ- $90 \%$, and a performance efficacy ratio of $80 \%$. ences for both groups. The strength towards

Table 2. Change in the indexes in the course of the implementation of the model for conditional training - Control group

\begin{tabular}{cccccccc}
\hline $\begin{array}{c}\text { Index } \\
\text { Module }\end{array}$ & F max & H max & H max1 & Hmax/game & H1/game & HL/game & Ef \\
\hline Beginning & 55 & 47 & 49 & 49 & 32 & 29 & 29 \\
$1-2$ & 84 & 62 & 65 & 63 & 47 & 41 & 42 \\
$3-4$ & 91 & 76 & 77 & 74 & 56 & 49 & 54 \\
\hline
\end{tabular}

Table 3. Change in the surveyed indexes in the course of the implementation of the model for conditional training - Experimental group

\begin{tabular}{cccccccc}
\hline $\begin{array}{c}\text { Index } \\
\text { Module }\end{array}$ & F max & H max & H max1 & Hmax/game & H1/game & HL/game & Ef \\
\hline Beginning & 52 & 42 & 50 & 49 & 30 & 25 & 27 \\
$1-2$ & 91 & 66.5 & 71 & 69 & 46 & 38 & 44 \\
$3-4$ & 88 & 77.5 & 85.5 & 84 & 64 & 59 & 65 \\
\hline
\end{tabular}

The statistical analysis of within-group shown in tables 4 to 6 . All differences are stadifferences of studied parameters between the tistically significant at $p \leq 0.05$. end of module 2 and the end of module 4 is

Table 4. Differences between module 2 and module 4 National Volleyball Team

\begin{tabular}{|c|c|c|c|c|c|c|c|c|}
\hline \multirow{3}{*}{ Differences } & \multicolumn{5}{|c|}{ Paired Differences } & \multirow{3}{*}{$\mathbf{t}$} & \multirow{3}{*}{ df } & \multirow{3}{*}{$\begin{array}{c}\text { Sig. } \\
\text { (2-tailed) }\end{array}$} \\
\hline & \multirow[t]{2}{*}{ Mean } & \multirow[t]{2}{*}{ Std. Dev. } & \multirow{2}{*}{$\begin{array}{l}\text { Std. Error } \\
\text { Mean }\end{array}$} & \multicolumn{2}{|c|}{$\begin{array}{l}\text { 95\% Confidence Interval } \\
\text { of the Difference }\end{array}$} & & & \\
\hline & & & & Lower & Upper & & & \\
\hline $\mathrm{F}_{\text {max }}$ & -2.84 & 16.622 & 3.71 & -10.62 & 4.93 & -.765 & 19 & .454 \\
\hline $\mathrm{H}_{\max }$ & 8.89 & 12.41 & 2.77 & 3.08 & 14.71 & 3.205 & 19 & .005 \\
\hline $\mathrm{H}_{\max 1}$ & 11.77 & 16.70 & 3.73 & 3.95 & 19.59 & 3.150 & 19 & .005 \\
\hline $\mathrm{H}_{\max }$ game & 12.98 & 18.36 & 4.10 & 4.38 & 21.57 & 3.162 & 19 & .005 \\
\hline H1 game & 11.98 & 15.35 & 3.43 & 4.79 & 19.16 & 3.490 & 19 & .002 \\
\hline
\end{tabular}




\begin{tabular}{ccccccccc}
\hline HLgame & 15.77 & 12.57 & 2.81 & 9.89 & 21.65 & 5.611 & 19 & .000 \\
Ef & 18.66 & 13.75 & 3.07 & 12.22 & 25.09 & 6.068 & 19 & .000 \\
\hline
\end{tabular}

Table 5. Differences between module 2 and module 4 control group

\begin{tabular}{|c|c|c|c|c|c|c|c|c|}
\hline \multirow{3}{*}{ Differences } & \multicolumn{5}{|c|}{ Paired Differences } & \multirow{3}{*}{$\mathbf{t}$} & \multirow{3}{*}{ df } & \multirow{3}{*}{$\begin{array}{c}\text { Sig. } \\
\text { (2-tailed) }\end{array}$} \\
\hline & \multirow{2}{*}{ Mean } & \multirow{2}{*}{$\begin{array}{l}\text { Std. De- } \\
\text { viation }\end{array}$} & \multirow{2}{*}{$\begin{array}{l}\text { Std. } \\
\text { Error } \\
\text { Mean }\end{array}$} & \multicolumn{2}{|c|}{$\begin{array}{l}\text { 95\% Confidence Inter- } \\
\text { val of the Difference }\end{array}$} & & & \\
\hline & & & & Lower & Upper & & & \\
\hline $\mathrm{F}_{\max }$ & 6.83 & 9.85 & 2.97 & .21 & 13.44 & 2.300 & 10 & .044 \\
\hline $\mathrm{H}_{\max }$ & 14.155 & 17.16 & 5.17 & 2.62 & 25.68 & 2.736 & 10 & .021 \\
\hline $\mathrm{H}_{\max 1}$ & 12.26 & 9.83 & 2.96 & 5.65 & 18.87 & 4.137 & 10 & .002 \\
\hline Hmaxgame & 10.60 & 14.40 & 4.34 & .93 & 20.28 & 2.443 & 10 & .035 \\
\hline H1game & 7.14 & 10.58 & 3.19 & .02 & 14.25 & 2.237 & 10 & .049 \\
\hline HLgame & 1.07 & 9.00 & 2.71 & -4.98 & 7.12 & .394 & 10 & .702 \\
\hline Ef & 11.98 & 15.53 & 4.68 & 1.54 & 22.42 & 2.558 & 10 & .028 \\
\hline
\end{tabular}

Table 6. Differences between module 2 and module 4 experimental group

\begin{tabular}{|c|c|c|c|c|c|c|c|c|}
\hline \multirow{3}{*}{ Differences } & \multicolumn{5}{|c|}{ Paired Differences } & \multirow{3}{*}{$\mathbf{t}$} & \multirow{3}{*}{ df } & \multirow{3}{*}{$\underset{\text { Sig. }}{\text { (2-tailed) }}$} \\
\hline & \multirow[t]{2}{*}{ Mean } & \multirow{2}{*}{$\begin{array}{l}\text { Std. De- } \\
\text { viation }\end{array}$} & \multirow{2}{*}{$\begin{array}{l}\text { Std. } \\
\text { Error } \\
\text { Mean }\end{array}$} & \multicolumn{2}{|c|}{$\begin{array}{l}\text { 95\% Confidence Inter- } \\
\text { val of the Difference }\end{array}$} & & & \\
\hline & & & & Lower & Upper & & & \\
\hline $\mathrm{F}_{\max }$ & -2.26 & 13.06 & 3.93 & -11.04 & 6.51 & -.575 & 10 & .578 \\
\hline $\mathrm{H}_{\max }$ & 9.25 & 9.36 & 2.82 & 2.96 & 15.54 & 3.277 & 10 & .008 \\
\hline $\mathrm{H}_{\max 1}$ & 10.28 & 12.86 & 3.87 & 1.64 & 18.92 & 2.652 & 10 & .024 \\
\hline $\mathrm{H}_{\max }$ game & 14.21 & 15.92 & 4.80 & 3.51 & 24.919 & 2.960 & 10 & .014 \\
\hline H1game & 15.26 & 11.91 & 3.59 & 7.25 & 23.27 & 4.247 & 10 & .002 \\
\hline HLgame & 18.86 & 12.70 & 3.83 & 10.32 & 27.40 & 4.923 & 10 & .001 \\
\hline $\mathrm{Ef}$ & 19.00 & 11.25 & 3.39 & 11.44 & 26.56 & 5.599 & 10 & .000 \\
\hline
\end{tabular}

When implementing the model, we used the strategy of parallel-consecutive development of physical qualities, their becoming motor qualities and their consecutive turning into abilities for their manifestation and transformation in performance abilities in competitive environment. The module scheme we used comprised a purposeful staged training for development of one or more certain qualities while forming functional base for improvement of other even more narrowly specialized ones which are significant for the volleyball game. We paid due attention to the general physical training (GPT) and its importance for prevention of sports injuries and the maintenance of good health condition. Moreover, we aimed not only at providing a momentary training impact but also at achieving post-training (successive) effect from the already used means on the ones to be used later on. Thus, we ensured the overlapping of training effects and possibilities for mutual potentiating of the developed motor qualities. This "synergeticpotentiating approach" enabled the athletes to maintain the reached conditioning level for a long time, respectively their fitness, especially with the presence of the included short unloading training micro cycles. 
The increase in the maximal force is identical for both groups, although the experimental group scores more at the end of module 2 . Conversely, the increase in explosive strength measured by jumping at height and with accelerations is respectively 6.5 and $7.5 \mathrm{~cm}$ higher in the experimental group. The considerably higher growth rate of maximum and explosive force in the first two modules, and the increase in the maximum jump height during play in both groups, shows the great importance of high-intensity strength training for developing these two motor abilities.

The largest differences in both groups surveyed were measured in the last two stages of the jump endurance development period - average jump height and last jump height. While in the first two stages the difference in the increase in these parameters was relatively small, during the next two stages it was significantly higher. For example, in the control group this increase was $9 \mathrm{~cm}$, and in the experimental of $17 \mathrm{~cm}$ (difference of $8 \mathrm{~cm}$ ). difference of 13 $\mathrm{cm}$ in the last jump indicator in the experimental group is even more noticeable. It proves a significantly higher level achieved in terms of in-game jump endurance. This is evident in the smaller difference between the average jump height and the last jump height in the experimental group. Consequently, the players in this group were able to maintain the jump height for a long time even when in-game fatigue built up. The efficiency factor Ef is also higher. For example, the difference of 4 units in its growth over the first two modules/periods in the control group may be considered relatively small compared to this achieved at the end of the preparation. The difference after the second two modules/periods increases twice, to 9 units. This means a higher work/performance efficiency was achieved. This could be mainly a result of the applied functional-coordination exercises in the experimental group and probably not of the acquired technical skills. This conclusion is also based on the fact that the technical and tactical training in the two groups - control and experimental - took place under the same training environment. It should be noted, however, that in parallel with the development of motor skills, especially through functional-coordination exercises in the control group, we also worked at improving the technique of jump entering, wavy arm and leg movements, pelvis inclusion technics at startup for catching a ball, etc.

\section{CONCLUSION}

After the analysis of the results from the conducted survey, the following conclusions were drawn:

1. The applied method for conditional training among elite female volleyball players from the experimental group showed the high degree of efficiency compared to the control group as regards:

- a significant increase in the level of their physical qualities;

- an increase in the play efficiency.

2. The result from the applied model for conditional preparation is the successful performance of the National Team during the year, namely:

- First place in the Tournament of the contenders for the Volleyball League of the nations and qualification for the League of the Nations in 2019;

- First place in the Golden European League; - $12^{\text {th }}$ place in the World Championship in Japan;

- $8^{\text {th }}$ place in the rang list of CEV.

The additional study conducted by the National Champion, the team of Maritza Plovdiv, showed the higher efficiency of the proposed software compared to the conventional Bulgarian conditioning training.

3. The introduced model for conditional 
preparation can be applied in other sports if its general principles are taken into consideration.

In order to create the introduced model of sports preparation we designed:

- Scientifically grounded overall concept and training program for conditional preparation in sport with an author's training system "Fit Motion-Professional", following the example with the sport volleyball (the program for conditional preparation has been recognized as a genuine author's product, designed as a result of creative work named "Training system Fit Motion" - Certificate №21/02.06.2014, issued by the Patent Office in the town of Plovdiv).

- Innovative methods and principles of training, part of which are based on an innovative approach which uses laws from quantum physics. Complete training complexes have been designed as well as modules taken from weightlifting, athletics, functionalcoordination, preventive-stabilizing, balance and other training methods.

- Author's gym and sports-recreational complex with author's equipment and facilities with the aim of testing the program product.

\section{REFERENCES}

Bobbert, M.F. (1990). Drop jumping as a training method for jumping ability.

Bomba, T.,Carrera, M. (2005). Periodization Training for Sports.

Eremiev, M. (2004). Promeni v nevrodinamikata pri praktikuvashti vodni sportive. Kineziterapia, No.1, pp. 21 - 25 // Еремиев, M. (2004). Промени в невродинамиката при практикуващи водни спортове. Кинезитерапия, № 1, стр. $21-25$

Eremiev, M. (2009). Fibularnata pozicia - osnoven faktor pri glezenna neastabilnost", Medicina i sport, No. 1, pp. $22-26 / /$ Еремиев, М. (2009). Фибуларната позиция основен фактор при глезенна нестабилност,
Медицина и спорт, № 1, стр. 22 - 26

Eremiev, M. (2010). Znachenieto na funkcionalnia podhod vav vazstanovitelnia period sled distorzii na glezenna stava, Medicina $i$ sport, No. 2, pp. 28 - 34 // Еремиев, М. (2010). Значението на функционалния подход във възстановителния процес след дисторзии на глезенна става. Медицинна и спорт, № 2, стр. 28-34

Gadev, M. (2015). Synergetic Conceptual Model of Conditioning Preparation in Soccer. Monograph, Sofia, Bolid Ins, pp. 118

Gadev, M. (2017). Essentials of the synergistic approach as a contemporary methodology for development of the Biosystems. Sport \& science, Sofia, vol. 2, pp. 13-27

Karabiberov, J. (2016). Conditioning training in volleyball, Monograph, Sofia, College of sport, Sofia, pp. 164

Linthorne, N. P. (2007). Biomechanics of the long jump. In Routledge Handbook of Biomechanics and Human Movement Science. London.

Mihailov, M., Pentceva, B., Bonova, I., Boyanov, D., Jeynov, B., Mateev, G., Stefanova, D. (2014). High peak oxygen consumption in rock climbing. 7-th, International Scientific Congress "Sport, Stress, Adaptation”, Extra issue, No. 1, pp. 95- 101

Miladinov, O. (1998). Izsledvane na vzrivnata sila pri 18-godishni futbolisti. Sport i nauka, No1, pp. 17-21 // Миладинов, О. (1998). Изследване на взривната сила при 18-годишни футболисти. Спорт и наука, № 1, стр. 17-21.

Miladinov, O., Dobrev, D. (2005). Izsledvane na efekta ot prilaganeto na atleticheski uprazhnenia $\mathrm{v}$ pliometrichen rezhim za razvivane na vzrivnata sila pri gimnastici, Leka atletika I nauka, o 1(5), pp. 47-50 // Миладинов, О., Добрев, Д. (2005). Изследване на ефекта от прилагането на атлетически упражнения в плиометричен режим за развиване на 
взривната сила при гимнастици, Лека avtorska metodika za razvitie na skorostnite атлетика и наука, № 1(5), стр. 47-50. vamozhnosti pri pluvci varhu sastezatelnite

Miladinov, O., Velin, V., Nikolova, M., rezultati v disciplinata $100 \mathrm{~m}$ svoboden stli Rankov, K., Stefanov, V., Filiov, V. (2009). mazhe. Sport i nauka, Izvanreden broi, No Izsledvane na niakoi biomehanichni I fizio- 1, pp. 95-101 // Панайотов, В, Ангелов, logichni parametri pri izpalnenie na silovi up- Б., Янкова, Н., Алексиева, Д., Лазаров, Л. razhnenia s razlichna skorost ot visokokvalifici- (2018). Влияние на авторска методика за rani lekoatleti, Leka atletikaInauka, No1(9), pp. развитие на скоростните възможности при 4-9 // Миладинов, О., Велин, В., Николова, плувци върху състезателните резултати в М., Ранков, К., Стефанов, Л., Фильов, В. дисциплината 100 м свободен стил мъже, (2009). Изследване на някои биомеханични Спорт и наука, Извънреден брой №1, стр. и физиологични параметри при изпълнение на силови упражнения с различна скорост от висококвалифицирани лекоатлети, Лека атлетика и наука, № 1(9), стр. 4-9.

Panayotov, V. (2018). Muskuli - kulturizam, fitnes, silova podgotovka, Sofia, Bolid Ins // Панайотов, В. (2018). Мускули културизъм фитнес, силова подготовка, София, Болид Инс 95-101

Ramey, M.R. (1976). Analysis of the same result long jump// Biomechanics. Baltimore

Suslov, F. (1999). Sports training in conditions of middle, Moscow.

Wilkie D. (1949). The relation between force and velocity in human muscle. Journal of Physiology.

Wilmore, J., Costill, D. (1994). Physiology

Panayotov, V., Angelov, B., Yankova, N., of sport and exercise. Champaign etc.: Human Alexieva, D., Lazarov, L. (2018). Vlianie na kinetics.

\section{Corresponding author:}

Julian Karabiberov

Track and field athletics department National Sports Academy „Vassil Levski“ 21, Acad. Stefan Mladenov str. Sofia 1700, Bulgaria E-mail: julian.karabiberov@gmail.com 